\title{
THE INFLUENCE OF USING KIT OF SCIENCE FOR KIDS TO ELEMENTARY SCHOOL STUDENTS' CONCEPT MASTERY
}

\author{
Yosi Gumala $^{1}$, Nunuy Nurkaeti ${ }^{2}$, Sani Aryanto ${ }^{3}$, \\ Ernawulan Syaodih ${ }^{4}$, Achmad Samsudin ${ }^{5}$ \\ ${ }^{1}$ Universitas Bhayangkara Jakarta Raya \\ ${ }^{2}$ Universitas Bhayangkara Jakarta Raya \\ ${ }^{3}$ Universitas Bhayangkara Jakarta Raya \\ ${ }^{4}$ Universitas Pendidikan Indonesia \\ ${ }^{5}$ Universitas Pendidikan Indonesia \\ 1'yosi.gumala@dsn.ubharajaya.ac.id, ${ }^{2}$ nunuy.nurkaeti@dsn.ubharajaya.ac.id, \\ ${ }^{3}$ sani.aryanto@dsn.ubharajaya.ac.id, ${ }^{4}$ ernawulansyaodih@upi.edu, ${ }^{5}$ achmadsamsudin@upi.edu
}

\begin{abstract}
This research was conducted to determine the increase in concept mastery of primary school students' teaching material through the use of media kits of science for kids. The research method used was quasiexperimental research using the matching only pretest and posttest control group design. The learning process uses the media kit of science for kids and the traditional learning media is used as a comparison. Learning takes place during four meetings, each learning process is carried out observing the implementation of learning activities. Research subjects were 55 students consisting of 28 students using the media kit of science for kids and 27 students with traditional learning media. The research instrument uses multiple-choice tests for concept mastery. The data analysis technique used n-gain mean data and non-parametric test t-test. The value of $n$-gain in class with a kit of science for kids media is 0.47 while in class with traditional learning media is 0.26 . The results showed that an increased understanding of the material using the kit of science for kids was higher than students who received traditional learning media.
\end{abstract}

Keywords: Concept Mastery, Science Media, Conceptual Change

\begin{abstract}
Abstrak
Penelitian ini dilakukan untuk mengetahui peningkatan pemahaman materi ajar siswa sekolah dasar melalui penggunaan media kit of science for kids. Metode penelitian yang digunakan adalah eksperimen semu dengan desain penelitian the matching only pretest and posttest control group design. Proses pembelajaran menggunakan media kit of science for kids dan media pembelajaran tradisional digunakan sebagai pembanding. Pembelajaran berlangsung selama empat pertemuan, setiap pembelajaran dilakukan proses observasi keterlaksanaan kegiatan pembelajaran. Subjek penelitian sebanyak 55 siswa yang terdiri dari 28 siswa mengunakan media kit of science for kids dan 27 siswa dengan media pembelajaran tradisonal. Instrumen penelitian menggunakan tes pilihan ganda untuk pemahaman materi ajar. Teknik analisis data menggunakan data rerata $n$-gain dan uji non-parametrik $U j i t$. Nilai n-gain pada kelas dengan media pembelajaran kit of science for kids sebesar 0,57 sedangkan pada kelas dengan media pembelajaran tradisional 0,28 . Hasil penelitian menunjukkan bahwa peningkatan pemahaman materi yang menggunakan kit of science for kids lebih tinggi dibandingkan siswa yang mendapatkan media pembelajaran tradisional.
\end{abstract}

Kata Kunci: Pemahaman Materi, Media Pembelajaran IPA, Perubahan Konsep

\section{INTRODUCTION}

Concept mastery is the ability of a person to understand or understand something after something is known and remembered. A student is said to understand something if he can provide an explanation or give a more detailed description of something using his own words 
(Sudijono, 2009). Concept mastery is a level of thinking ability that is one level higher than memory or memorization. Students' concept mastery in understanding material related to concepts is one part of learning outcomes, namely cognitive aspects. Abilities that include cognitive domains by Bloom include a variety of behaviors from the lowest to the highest levels, namely knowledge, understanding, application, analysis, evaluation, and creation (Warsita \& Nurjhani, 2018).

According to Purwandari (2014) the factors that cause the low student learning outcomes in science subjects are as follows: (1) the learning model applied by teachers in science learning is less innovative, (2) science learning activities are less varied so that the lack of activity students, (3) students' interest and motivation in participating in the science learning process is low, (4) the use of media in the science learning process is still limited, making it difficult for students to understand abstract learning material. Based on the aforementioned factors, the teacher's skill in selecting and applying learning models that are relevant to the needs of students and the characteristics of natural science subjects is one of the factors that can affect the quality of student learning outcomes. This is supported by the opinion of Susanto (2013, p. 166) which states that teachers have not been fully able to carry out science learning actively and creatively in engaging students through the application of learning models that vary based on the characteristics of the subject matter. Jenkins (2011) states the causes of students viewing science as an unattractive subject and often lack understanding when studying science because science learning is not relevant to everyday life experiences.

Based on observation activities found problems from the teacher, students, and learning outcomes. The teacher has not fully mastered a more effective learning model in the delivery of material and increased the ability of students needed at this time one of which is the ability to solve problems. This is proven by the teacher not introducing student material concretely, the media used is less than optimal, more one-way lectures does not vary the learning model, and has led students to find their own understanding through learning experiences. The teacher has not designed the surrounding environment and student experience in daily activities as a source and medium of learning.

For elementary school students grade III, IV, and V whose cognitive development level is at a concrete operational level, the learning model involving experience is very appropriate to apply. According to Jarvis (2011) at this stage, students are mature enough to use logical thinking or operations, but only for physical objects that exist today. Egocentric students at this stage are reduced and their abilities in conservation tasks become better. But without physical 
objects before them, students at the concrete operational stage still have great difficulty in completing logical tasks. That makes the delivery of science should be done thoroughly by involving concepts, instruments and good conditioning so that it gives a positive influence on learning (L.J Grabbau, 2017).

Implementation in learning by involving experience in primary schools requires media props or real experimental tools. The findings of Ningsih (2019) related to the use of educational media in learning in primary schools using practicum methods show that the use of educational tools and media in science learning can make students' understanding more permanent, students gain learning experiences that cannot be obtained in theory, students able to get to know and master the science tools better which ultimately has the knowledge and understanding of teaching material in more depth. Akpinar (2009) suggests that science teaching and learning should involve the use of material and media that are more interesting, this can encourage student involvement in learning science at the elementary school level and be able to maintain and expand student knowledge about science.

One of the experimental tools or demonstration tools that can be used is the KIT IPA. KIT is an educational teaching aid packaging system where all components or instruments are arranged in an integrated manner so that it can be used for various experiments by practical. Whereas the Natural Science KIT referred to in this study is a kit of science for kids which is a language transfer from KIT, while the intended students are specifically for fourth-grade elementary school students. Thus the kit of science for kids is a teaching aid or experiment tool that has been designed and compiled by the teacher with items related to the unit of study used in helping students to understand the science material of various objects found in elementary school students. It is expected that through real experimental activities, active involvement of students in learning can improve and understanding related teaching materials can be connected with students' daily lives.

In addition to understanding teaching material, learning activities are expected to be able to practice the ability to solve science problems such as understanding the problems faced, providing solutions, giving reasons, and providing alternative solutions. This needs to be given in view of the increasingly rapid development of the times, so students are able to follow global competition (Afifah, 2019). With the purpose of this investigation, the researchers required to be acquainted with the consequence of using the Kit of science media in the accumulative mastery of concepts. 


\section{METHOD}

The method used in this research is the quasi-experimental method. (Gall \& Borg, 2003, p. 402) say that referring to the limited research related to random samples is called quasiexperimental. The two classes were given different treatments but were given the same pretest and posttest, so the research design used was the matching-only pretest-posttest control group design (Fraenkel, 2012, p. 248). Furthermore, the score from the pretest results is compared with the posttest score to see the increase or change in the score obtained.

In this study, the assessment of teaching material understanding is devoted to aspects of understanding (C2) in the taxonomy of Anderon \& Krathwol such as estimating, explaining, classifying, characterizing, detailing, associating, comparing, calculating, contrasting, changing, maintaining, describing, interweaving, distinguishing, discussing, discussing, explore, exemplify, explain, pattern, expand, conclude, predict, summarize, and describe. But in research, because time and experiments are only relevant to only a few aspects researchers exemplify, classify, compare, explain and interpret. This is adjusted to the assessment in aspects of Anderson \& Krathwohl's understanding. Tests conducted to determine the understanding of the material using multiple choices. The multiple-choice test used only focuses on matter and force changes with questions including friction, gravity, and electromagnetic forces. The selection of more specific material is needed so that students are easier to do. This is supported by the opinion of Nelson (2014) which states the questions asked to students should be in accordance with the topics and knowledge that have been considered.

\section{RESULTS AND DISCUSSION}

\section{Results}

Results to find out whether the treatment is given, namely the kit of science for kids learning media is able to significantly increase students' understanding of teaching material, compared to conventional media. In the elementary school science laboratory, there are various kinds of tools that can support students in conducting various varieties of science experiments, one of which is the Kit of science for kids. Several categories of science tools are confidential on numerous basis. One classification is based on completeness of comprehensiveness settings. Through activities that are designed based on the framework of each proposed step can improve student competency. The kit of science for kids is the designation of the natural science supports used for experiments in learning science in the classroom. In general, the difference 
in the average score of understanding of teaching material obtained by the class with the kit of science for a kid learning model is 0.47 and the conventional learning model class is 0.26 .

\section{Discussion}

Based on the data processing of the results of the pretest understanding of teaching material, it was shown that the class with the kit of science for kids learning media and the class with conventional learning media had different understanding abilities. The test class got the kit of science for kids learning treatment while the comparison class got conventional learning treatment. Of the two treatments, both those using the kit of science for kids and conventional learning turned out to both be able to improve teaching material understanding. However, the improvement experienced by students who learn through learning using kits of science for kids is generally higher than students who study with conventional learning.

Through the statistical analysis, it can be proven that the increase in understanding of teaching materials achieved by the class with the media kit of science for kids is significantly different than what is achieved by the class with conventional learning models. Thus, it can be said that learning using the kit of science for kids can make a positive contribution to increasing understanding of teaching material. The provision of learning models that are in accordance with the material effectively can increase the understanding of Natural Sciences (Schiever, 2017). This is because during the learning process students are required to find, process, and form their own theories based on the experiments they do, so they unconsciously practice understanding the teaching material. This is in line with Balim's explanation (2009, p. 2) which explains that the discovery of material and ideas in natural science takes place over experiments and investigations of natural phenomena through the media kit of science for kids. While the experiment itself one of them can be done using a kit. As Jones et al. (2014, p. 2374) said, kits can involve students in experimental activities to find things related to science material through questions, including some forms of data collection, data interpretation, and assessment after using KIT.

When viewed from the magnitude of the increase in understanding of teaching materials in general in the classroom with the media kit of science for kids, it can be seen that the average score of teaching material understanding in the pretest is relatively low compared to the acquisition of the final score (posttest) after learning. As for the form of treatment in the classroom with learning media kit of science for kids, while the comparison class students get conventional learning on the concepts of friction, gravity, and electromagnetic forces. In the 
class with the media kit of science for kids, if seen from the increase in the average $\mathrm{N}$-gain score, the understanding of teaching material is quite significant, the results can be seen at 0.47 in the medium category, whereas in the class with conventional learning media the average score increase in the $\mathrm{N}$ - the gain is 0.26 in the low category. Furthermore, when viewed according to the cognitive aspect students still have difficulty in answering the test on the aspect of providing the lowest alternative solution compared to the increase in the average $\mathrm{N}$-gain score of other aspects. While what happens in the classroom with conventional learning media cognitive aspects have increased, all of which are of low category.

Therefore, it can be concluded that the learning media kit of science for kids can significantly increase the understanding of teaching materials, especially in the mastery of the concept of friction. gravity and electromagnetism. This is relevant to the results of research conducted by Purwandari (2014) which results show that there are differences in understanding of the concepts of science and learning processes that prioritize visual, aesthetic and kinesthetic among students who get learning kits of science for kids compared to conventional learning. This is in line with research conducted by Purnomo (2017) whose results show that there are differences in student learning outcomes between students who take the media kit of science for kids learning with students who take conventional learning. However, the increase in Ngain that occurred in the classroom with the learning media kit of science for kids was only categorized as moderate, this could be due to the learning process at the first meeting there were still obstacles. As for some of the obstacles that become less optimal learning activities are students, teachers, learning time, and textbooks.

Student factors include lacking student readiness. Maharbid (2018) states that readiness is a willingness to respond or react. Based on the understanding of readiness expressed by maharbid, it can be said that students who are ready to learn are students who respond or react to learning activities. While in the learning activities carried out there are still many students who are not ready to accept learning, this is still the presence of group members who do not work and help their colleagues both in conducting experiments and answering questions in student worksheets.

The teacher factor includes explaining the planned activities to be carried out and the rules for playing in the group. This is supported by the opinion of Darmadi (2012, p. 4) which explains that the activities explained in learning aim to help students understand concepts, laws, and procedures. objectively, guide students objectively, guide students to understand questions, increase student involvement, gives students the opportunity to live the reasoning process and 
get feedback on student understanding. This is in line with the opinion of Gillespie (2007, p. 5) which states that in order for students to learn effectively through experiments, teachers must pay attention to four things, including the level of guidance provided, students' ability to work independently, plan investigation or experimental steps, the nature of the problem proposed (requires answers), availability of learning resources, and realistic allocation of time for implementation. Next is the weakness in guiding students in the discussion equally. Evidenced by the reluctance of teachers to go around to guide students in discussions. This is also supported by the opinion of Gumala $(2016$, p. 5) which explains that the components guiding small group discussions include: 1) Focusing students' attention; 2) Clarify the opinions of students; 3) Analyzing student views; 4) Increase student contributions; 5) Distributing students' views, and 6) Closing the discussion.

The next factor is the learning time. The allocation of learning time at each meeting is $3 \times 35$ minutes predetermined between the researcher and the teacher written in the learning syntax. But it was seized by the noise of students. Especially what happens at the first meeting, where students are not familiar with the learning provided (Nurkaeti, 2019). Where this has an impact on the course of learning that results in less than the maximum in the delivery of learning material (Gumala, 2019; Syaodih, 2019). The limited availability of learning resources in the form of textbooks also becomes an obstacle. Where in learning to use the kit of science for kids there is a learning stage which is the verification stage that requires literary support to confirm the results of experiments and student discussions in each group.

\section{CONCLUSION}

Based on the results of research and discussion that has been done, it can be concluded as follows, Increased understanding of teaching materials among elementary school students who get media kits of science for kids is higher than elementary school students who learn through traditional learning media.

\section{REFERENCES}

Afifah, R. N., Syaodih, E., Suhandi, A., Maftuh, B., Hermita, N., Handayani, H., ... \& Samsudin, A. (2019). Develop children's science process skills through building activities in center of beam: optical geometry on focus. In Journal of Physics: Conference Series (Vol. 1280, No. 5, p. 052016). IOP Publishing.

Akpınar, E., Yıldız, E., Tatar, N., \& Ergin, Ö. (2009). Students' attitudes toward science and technology: an investigation of gender, grade level, and academic achievement. Procedia - Social and Behavioral Sciences, 1 (1) 2804-2808. 
Balım, A., G. (2009). The Effects of Discovery Learning on Students' Success and Inquiry Learning Skills. Eurasian Journal of Educational Research, Issue 35, Spring 2009, 1 20.

Fraenkel, et al. (2012). How to Design and Evaluate Research in Education. New York: Mc Graw-Hill.

Gumala, Y. (2016,). Video-based Blogging in Learning (vlog) to Develop The Interaction of Teachers and Students. In of The International Seminar on Philosophy of Education (p. 215).

Gumala, Y., Sopandi, W., Kadarohman, A., \& Sujana, A. (2019). Analysis of air pollution conception on pre-service elementary teachers. In Journal of Physics: Conference Series (Vol. 1157, No. 4, p. 042023). IOP Publishing.

Gumala, Y., Suhandi, A., Syaodih, E., Maftuh, B., Hermita, N., \& Samsudin, A. (2019). Facilitating of fourth grade students problem solving skills on gravity. In Journal of Physics: Conference Series (Vol. 1157, No. 3, p. 032041). IOP Publishing.

Gumala, Y., Suhandi, A., Syaodih, E., Maftuh, B., Ningsih, A. R., Afiffah, R. N., ... \& Samsudin, A. (2019). Facilitating of fourth grade student's problem solving skills on friction. In Journal of Physics: Conference Series (Vol. 1280, No. 5, p. 052009). IOP Publishing.

Jarvis, M. (2011). Teori-Teori Psikologi, Pendekatan Modern Untuk Memahami. Perilaku, Perasaan \& Pikiran Manusia. Bandung: Nusa Media.

Jenkins, L. L. (2011). Using citizen science beyond teaching science content : a strategy for making science relevant to students' lives. Cultural Studies of Science Education, 6 (2), 501-508.

Jones, Gail., Robertson, L., Gardner, GE., Dotger, S., Blanchard, MR. Differential. (2012) Use of Elementary Science Kits. International Journal of Science Education 34152371 2391.

Maharbid, D. A., Maharbid, T. A., Gumala, Y., \& Herman, T. (2018). Mobile game design for understanding fractional conception in elementary school. In International Conference on Mathematics and Science Education of Universitas Pendidikan Indonesia (Vol. 3, pp. 836-841).

Nelson, J. D., Divjak, B., Gudmundsdottir, G., Martignon, L. F., \& Meder, B. (2014). Children's sequential information search is sensitive to environmental probabilities. Cognition, 130, 74-80.

Ningsih, A. R., Afifah, R. N., Gumala, Y., Handayani, H., Suhandi, A., Syaodih, E., ... \& Samsudin, A. (2019). A preliminary study: how is extent the fourth-grade students understanding of the magnetic force?. In Journal of Physics: Conference Series (Vol. 1280, No. 5, p. 052048). IOP Publishing.

Nurkaeti, N., Aryanto, S., \& Gumala, Y. (2019). READ ALOUD: A LITERACY ACTIVITY IN ELEMENTARY SCHOOL. PrimaryEdu-Journal of Primary Education, 3(2), 5561. 
Purwandari, Ayu. (2014). Model Experiential Learning Bernuansa Vak (Visual, Auditori, Kinestetik) Berpengaruh Terhadap Hasil Belajar Ipa Kelas V Sd Gugus Letkol Wisnu. Jurnal Mimbar PGSD Universitas Pendidikan Ganesha, Vol: 2 No: 1.

Schiever, julia. et al. (2017). Elementary School Children's Understanding of Science: The Implementation of an Extracurricular Science Intervention. Contemporary Educational Psychology

Sudijono, A. (2009). Pengantar Evaluasi Pendidikan. Jakarta: Rajawali Pers.

Susanto, Ahmad.(2014). Teori Belajar dan Pembelajaran di Sekolah Dasar. Jakarta : Kencana

Syaodih, E., Suhandi, A., Maftuh, B., Hermita, N., Handayani, H., Nurafifah, R., ... \& Samsudin, A. (2019). Identifying kindergarten children's idea about heat and temperature concept. In Journal of Physics: Conference Series (Vol. 1280, No. 5, p. 052018). IOP Publishing.

Trivena, T., Widodo, A., Sopandi, W., Budiarti, T., \& Gumala, Y. (2018). Fifth-grade elementary school perception of STEM. In International Conference on Mathematics and Science Education of Universitas Pendidikan Indonesia (Vol. 3, pp. 475-480).

Warsita A N, Nurjhani M, Shintawati R. (2018). Relationship between Students' Concept Mastery and The Ability to Assess Source Credibility through Problem Based Learning in Environmental Pollution Concept. Indonesian Journal of Biology Education, 1(1): $1-7$. 